\title{
Hubungan Konsep Diri dan Kecerdasan Emosional Terhadap Hasil Belajar Biologi Siswa Di Kelas XI IPA SMA
}

\author{
Siti Khadizah Harahap* dan Herbert Sipahutar \\ Program Studi Pendidikan Biologi, FMIPA, Universitas Negeri Medan, Medan \\ "E-mail : sitikhadizah1994@gmail.com
}

\begin{abstract}
The purpose of this study was to determine the student's self concept relationship relationship and emotional intelligence on student's achievement in eleventh science grade SMA Se-kota Tebingtinggi Academic Year 2016/2017. Questionnaire was used to know the self concept and emotional intelligence, while the learning out comes gotten from student's biology exam score in last semester document. From the results of the test data requirements known that the relationship of self-concept and emotional intelligence on students achievement, that calculated by testing the coefficient of determination, percentage of contribution obtained 59,29\% for selfconcept of students, $54,76 \%$ for the emotional intelligence of learning, and 62,4\% for the emotional intelligence and self-concept on student biology achievement. From the research, results can be obtained that Ha accepted because there is a significant relationship between self-concept and emotional intelligence on student's achievement in eleventh science grade SMANegeri Se-kota Tebingtinggi Academic Year 2016/2017.
\end{abstract}

Keywords: Self Concept, Emotional Intelligence, Biology Achievement

\section{PENDAHULUAN}

Intelegensi dan konsep diri sangat mempengaruhi prestasi. Namun, Goleman (2001), mengemukakan bahwa banyak orang yang memiliki keahlian dan potensi akademik (IQ) yang sangat baik, namun mengalami kegagalan dalam kehidupannya. Kelemahan fatal dalam setiap kasus yang ditemuinya berada pada domain emosi. Emosi yang tak dapat dikendalikan dapat membuat orang pandai menjadi bodoh. Orang yang kurang cerdas secara emosi tidak akan dapat menggunakan kemampuan kognitifnya untuk mencapai potensi maksimal.

Aspek akademik hanya merupakan bakat yang dimiliki peserta didik, kecerdasan akademik praktis tidak menawarkan persiapan untuk menghadapi gejolak atau kesempatan yang ditimbulkan oleh kesulitan-kesulitan yang dihadapi. Peserta didik yang memiliki kemampuan akademik yang baik, akan tetapi tidak didukung oleh kecerdasan emosi yang tinggi akan, mempengaruhi hubungannya dengan orang disekitarnya (Mulyati, 2005). Sementara itu, peserta didik dengan EQ tinggi akan berupaya menciptakan keseimbangan dalam dirinya, bisa mengusahakan dalam kebahagian pada dirinya sendiri dan bisa mengubah sesuatu yang buruk menjadi sesuatu yang positif dan bermanfaat bagi kesuksesan belajar dirinya.
Apabila seseorang siswa berpikir akan berhasil, ini merupakan kekuatan atau dorongan baginya untuk mencapai kesuksesannya. Begitu juga sebaliknya, jika siswa berpikir akan gagal, maka hal ini sama saja dengan mempersiapkan kegagalannya. Dengan kata lain konsep diri adalah penilaian tentang diri kita yang meliputi apa yang dipikirkan dan apa yang kita rasakan. Hal ini dikarenakan konsep diri dianggap sebagai kunci yang mengatur dan mengarahkan perilaku manusia.

Berdasarkan laporan Hidayatullah (2014),ternyata siswa MTs Al-Wasiah mengalami kurangnya perkembangan kecerdasan emosional seperti motivasi diri yang rendah, kurang menyesuaikan diri dengan oranglain, kurang menghargaiorang lain, sehingga terhambatnya proses belajar disekolahnya.

Dalam kaitan pentingnya konsep diri dan kecerdasan emosional pada diri siswa sebagai bagian faktor penting untuk meraih prestasi akademik, maka dalam penyusunan skripsi ini peneliti ingin meneliti: "Hubungan Konsep Diri dan Kecerdasan Emosional Terhadap Hasil Belajar Biologi Siswa di Kelas XI IPA SMA Negeri Se-Kota Tebingtinggi Tahun Pembelajaran 2016/2017". 


\section{METODE PENELITIAN}

\section{Lokasi Penelitian}

Penelitian ini dilaksanakan di SMANegeri Se-Kota Tebingtinggi pada bulan Oktober sampai Desember 2016.

\section{Populasi, Sampel dan Teknik Penyuplikannya}

Populasi penelitian adalah seluruh siswa kelas XI IPA SMANegeri Se-Kota Tebingtinggi Tahun Pembelajaran 2016/2017, (700 siswa).Sampel diambil dengan cara Purposive, sebanyak 127 orang kelas XI IPA.

\section{Instrumen Teknik Pengumpulan Data}

Angket digunakan untuk memperoleh data konsep diri dan kecerdasan emosional siswa.angket tersebut sebelum digunakan sebagai alat pengumpul data terlebih dahulu diuji kelayakannya oleh validator yaitu Ibu Prof. Dr. Sri Milfayetty, MS. Kons, dimana angket yang dibuat terdiri dari 35 item untuk konsep diri dan 35 item untuk kecerdasan emosional yang diberi skor dengan pernyataan. Dimana angket tersebut berdasarkan pendapat Calhoun dan Acocella (1990) dan Goleman
(2001). Sedangkan hasil belajar siswa diperoleh nilai ulangan biologi akhir semester ganjil siswa yang diperoleh dari guru mata pelajaran biologi.

\section{Teknik Analisis Data}

Teknik analisis data meliputi: (1) analisis deskriptif, (2) analisis kuantitatif yang meliputi analisis korelasi partial, uji t, analisis regresi ganda, dan uji F.Uji pengolahan data dimulai dari mencari nilai rata-rata (mean), mencari standard deviasi, uji normalitas dan uji liniearitas.

\section{HASIL PENELITIAN}

Berdasarkan data konsep diri yang diperoleh dari hasil angket penelitian terhadap 127 respondendari nilai rata-rata skor siswa sebesar 103, 39, varians nya 84, 80 sedangkan standart deviasi sebesar 9, 21. Skor minimum 80 dan skor maksimum sebesar 130. Berdasarkan hasil kriteria penilaian konsep diri diperoleh rata-rata ideal sebesar 87, 5 dengan standar deviasi ideal sebesar 17, 5. Dapat dilihat pada Gambar 1.

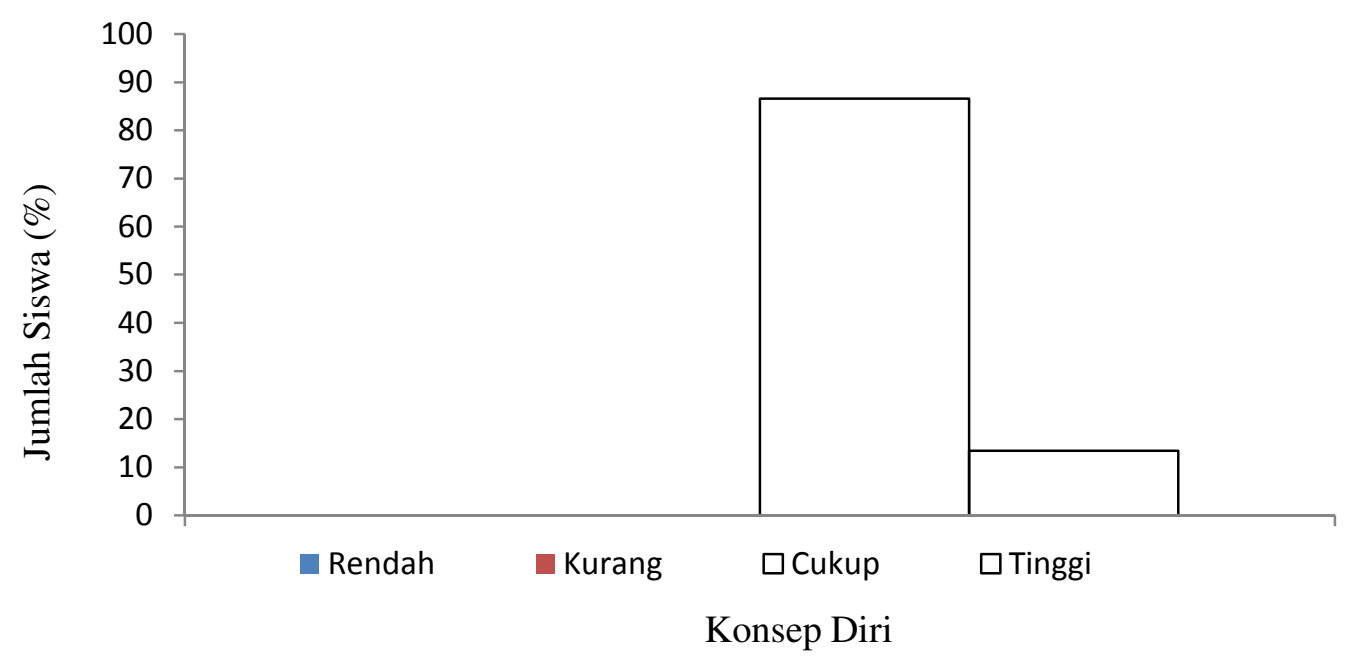

Gambar 1. Distribusi Siswa Berdasarkan Skor Angket Konsep Diri

Dari Grafik diatas dapat dilihat, tidak ada siswa yang memiliki skor konsep diri pada kategori rendah dan kurang. Untuk kategori cukup terdapat 110 siswa dan kkategori tinggi ada 17 siswa. Data kecerdasan emosional yang diperoleh dari hasil penelitian dengan jumlah responden sebanyak 127orang diketahui skor tertinggi 129 dan skor terendah 61 dengan ratarata 94,70 dan standard deviasi12,96 yang varians sebesar 168, 08. Berdasarkan kriteria penilaian kecerdasan emosional diperoleh ratarata ideal sebesar 87,5 dengan standar deviasi ideal 17,5. Dapat dilihat dari Gambar 2. 


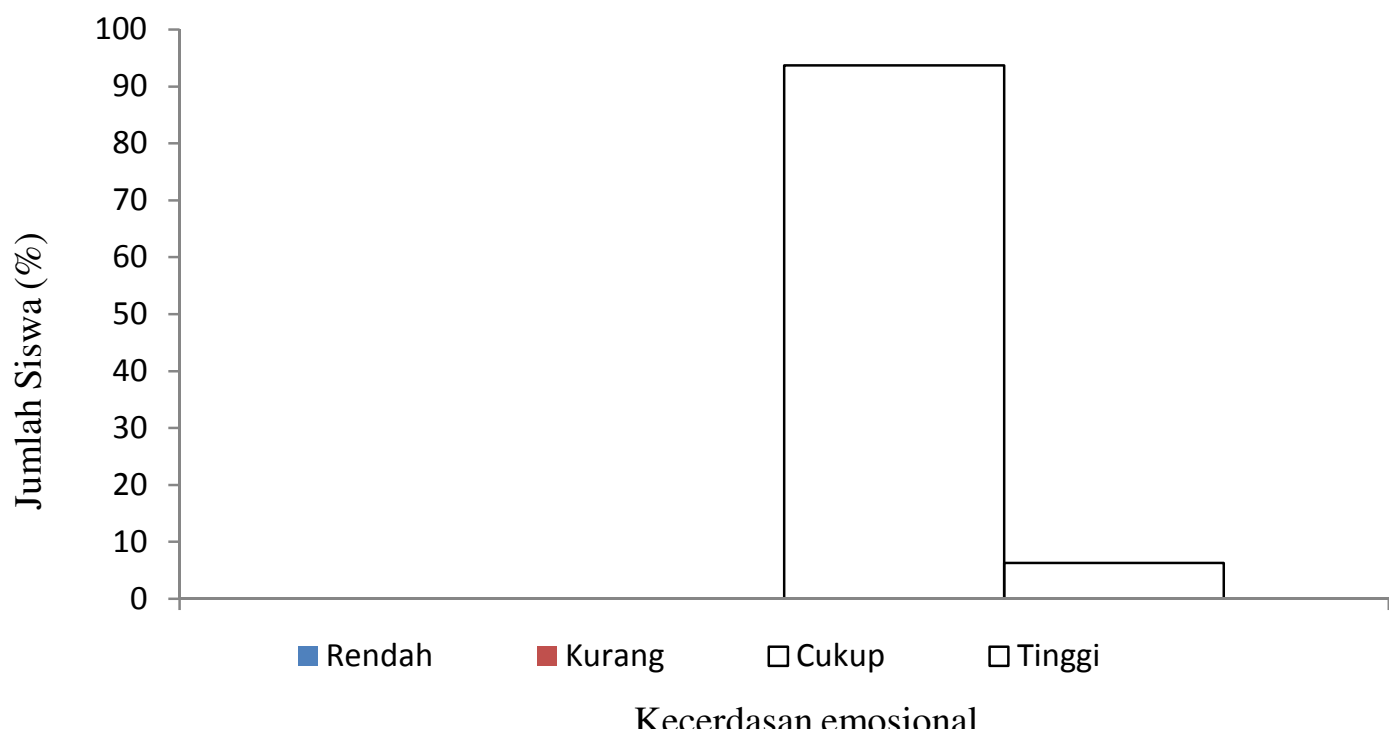

Gambar 2. Distribusi Siswa Berdasarkan Skoe Kecerdasan Emosional

Pada Grafik 2, tampak dengan jelas bahwa siswa memiliki kecerdasan emosional dengan kategori cukup yang memiliki jumlah 119 orang siswa, sedangkan pada kategori tinggi hanya memiliki 8 orang siswa. Untuk kategori rendah dan kurang tidak ada ditemukan pada siswa.

Hasil belajar biologi siswa dapat dilihat pada Tabel 1 .

Tabel 1. Hasil belajar biologi siswa.

\begin{tabular}{llc}
\hline Ukuran Sampel & $:$ & 127 \\
\hline Rata - Rata & $:$ & 9,05 \\
\hline Standar deviasi & $:$ & 3,01 \\
\hline Skor Minimal & $:$ & 83 \\
\hline Skor Maksimal & $:$ & 98 \\
\hline
\end{tabular}

Untuk mengetahui persentase kontribusi (sumbangan efektif) variabel bebas dengan variabel terikat (konsep diri dan kecerdasan emosional dengan hasil belajar biologi siswa) diadakan uji koefisien determinasi. Diperoleh harga koefisien korelasi konsep diri dengan hasil belajar sebesar 0,77. Selanjutnya untuk menentukan besarnya sumbangan efektif konsep diri dengan hasil belajar, koefisien determinasi dihitung dengan menguadratkan koefisien korelasi 0,77 yang telah ditemukan
$(0,5929)$ dan selanjutnya dikalikan dengan $100 \%$ sehingga hasil yang didapat sebesar $59,29 \%$ yang berarti variabel konsep diri memberikan sumbangan efektif sebesar 59,29\% dengan hasil belajar biologi siswa kelas $\mathrm{X}$ SMANegeriSe-Kota Tebingtinggi T.P. 2016/2017, sementara 54,76\% lagi ditentukan oleh faktor kecerdasan emosional dan faktor lainnya. Untuk persentase kontribusi (sumbangan efektif) kecerdasan emosional dengan prestasi belajar diperoleh harga koefisien korelasi 0,74 yang dikuadratkan $(0,5476)$ dan dikalikan $100 \%$ sehingga didapat hasil sebesar $54,76 \%$ yang berarti variabel kecerdasan emosional memberikan sumbangan efektif sebesar $54,76 \%$ dengan hasilbelajar siswa, sementara $45,24 \%$ ditentukan oleh faktor konsep diri dan faktor lainnya. Untuk persentase kontribusi (sumbangan efektif) konsep diri dan kecerdasan emosional dengan hasil belajar diperoleh harga koefisien korelasi ganda sebesar 0,79 yang dikuadratkan $(0,6241)$ dan dikalikan $100 \%$ sehingga didapat hasil sebesar $62,41 \%$ yang berarti variabel konsep diri dan kecerdasan emosional secara bersamasama memberikan sumbangan efektif sebesar $62,41 \%$ terhadap prestasi belajar siswa, sementara $37,59 \%$ lagi ditentukan oleh faktor lainnya. 


\section{PEMBAHASAN}

Pengolahan data yang dihasilkan dari perhitungan yang dibuktikan nilai $R_{y 1}=0,77$ dari daftar distribusi $\mathrm{r}$ dengan $\alpha=0.05$ dan $\mathrm{n}=$ 127 diperoleh $r_{\text {tabel }}=0.176$. Sehingga dapat diketahui bahwa $R_{y .12} \geq r_{\text {tabel }}$. Faktor konsep diri mempengaruhi hasil belajar biologi siswa sebesar 59,29\%. Nilai $R_{y 1}$ berada dalam kategori cukup. Kemampuan mengkonsep diri mendorong setiap individu terus berusaha dan memperbaiki segala kekurangan dan kelemahan pada dirinya yang menyebabkan setiap individu mau belajar dan terus belajar demi terwujud cita-citanya dimasa yang akan datang (Ahmad, 2015).

Hasil data perhitungan yang dibuktikan dari nilai $R_{y 2}=0,74$ dari daftar distribusi $\mathrm{r}$ dengan $\alpha=0.05$ dan $\mathrm{n}=127$ diperoleh $r_{\text {tabel }}=0.176$. Sehingga dapat diketahui bahwa $R_{y .12} \geq r_{\text {tabel }}$. Faktor kecerdasan emosional mempengaruhi hasil belajar biologi siswa sebesar $54,76 \%$. Nilai $R_{y 2}$ berada dalam kategori cukup.

Berdasarkan hasil analaisis data persamaan regresi $\mathrm{Y}$ atas $\mathrm{X}_{1}$ adalah $\widehat{\mathrm{Y}}=63,97+0,26 X$ yang ditunjukkan oleh Gambar 3.

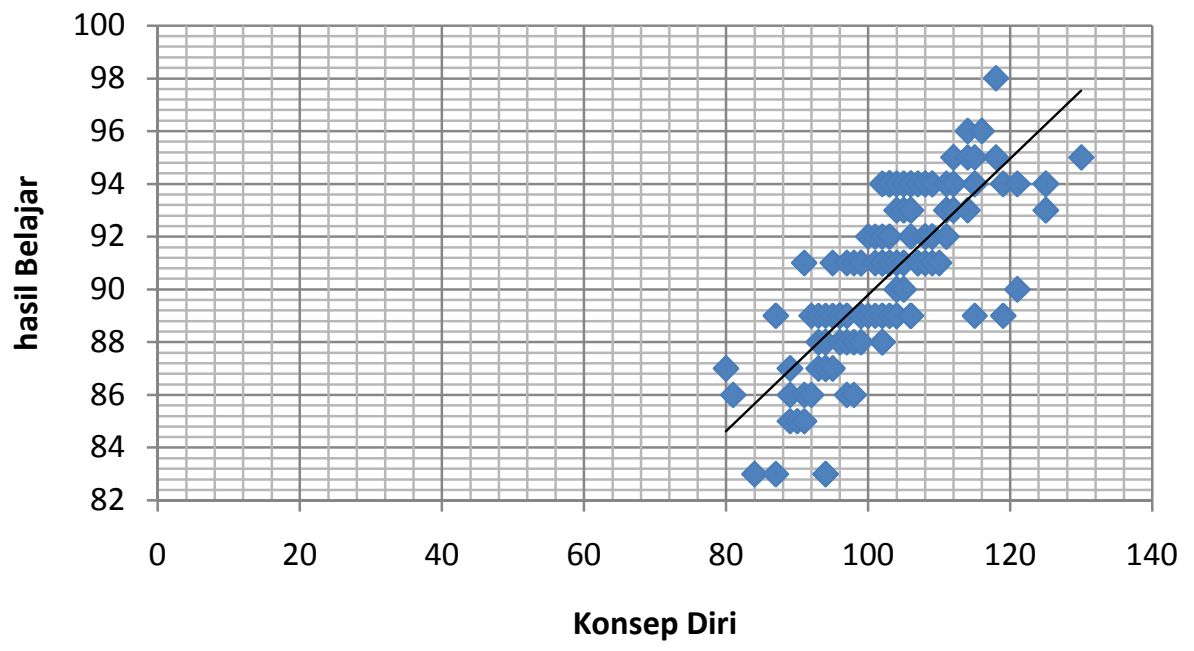

Gambar 3. Hubungan Konsep Diri Dengan Hasil Belajar Biologi

Berdasarkan hasil analaisis data persamaan yang ditunjukkan oleh Gambar 4. regresi $\mathrm{Y}$ atas $\mathrm{X}_{2}$ adalah $Y=73,50+0,18 X$

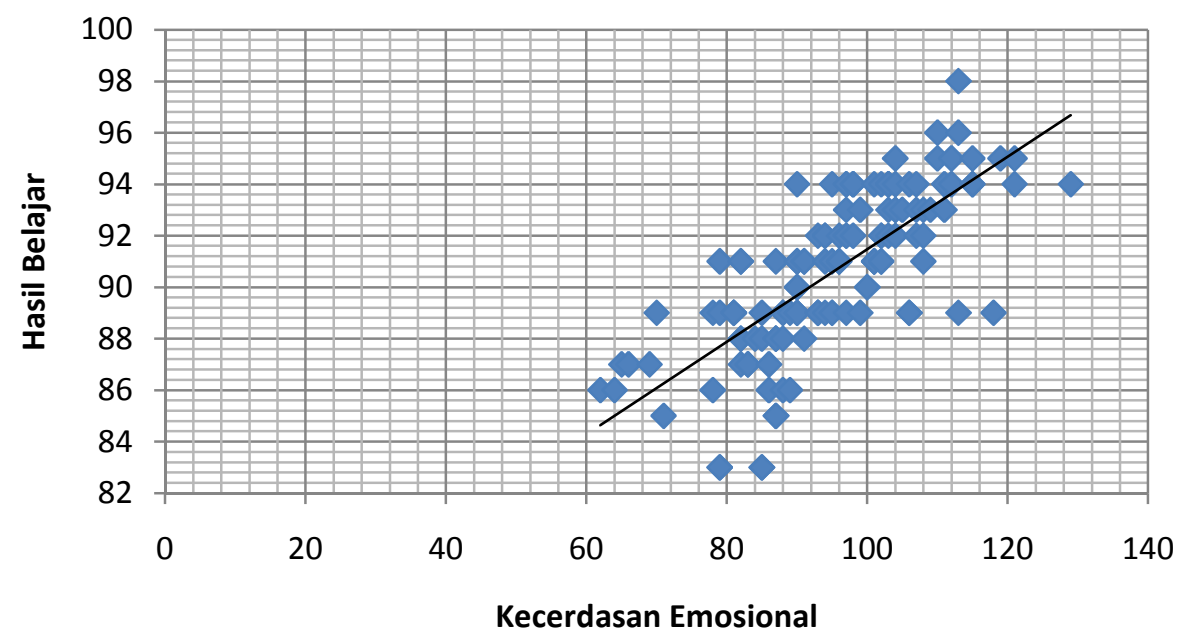

Gambar 4. Hubungan Kecerdasan Emosional Dengan Hasil Belajar Biologi 
Hal ini sejalan dengan hasil penelitian yang dilakukan (Pamungkas dkk, 2014) menunjukkan bahwa terdapat pengaruh yang signifikan dari kecerdasan emosional terhadap hasil belajar. Hal ini ditunjukkan dengan besarnya koefisien korelasi yaitu 0,4821 dan koefisien determinasi pada X terhadap Y adalah 0,2324. Sumbangan efektif kecerdasan emosional dihitung dengan cara mengalikan SR (100\%) dengan koefisien determinasi yaitu sebesar 23,24\%. Winarni (2014) menunjukkan bahwa ada pengaruh positif yang signifikan antara kecerdasan emosional dan prestasi belajar Biologi siswa yang ditunjukkan dengan besar nilai korelasi, dimana rata-rata 109,38 dengan skor terendah 86 dan skor tertinggi 124 berada pada kategori sangat baik, dimana nilai signifikansi yang lebih besar dari 0,05 dan $F_{\text {hitung }}$ lebih kecil dari $F_{\text {tabel }}$. Hasil penelitian Firdaus (2012) menunjukkan kecerdasan emosional pada umumnya termasuk dalam kategori tinggi dengan skor rata-rata berada pada interval 152-174 dengan kualifikasi "kecerdasan emosional tinggi". Pengaruh kecerdasan emosional terhadap hasil belajar Biologi siswa berdasarkan hasil analisis diperoleh nilai $\mathrm{F}=63,095$ signifikansi pada taraf $5 \%$, nilai $r=0,689$ dan $t=7,943$, hal ini berarti ada pengaruh yang positif dan signifikan kecerdasan emosional terhadap hasil belajar Biologi siswa. Menurut Purnaningtyas (2010) menunjukkan bahwa terdapat hubungan yang positif dan signifikan sebesar 0,349 antara kecerdasan emosi dengan prestasi belajar siswa, sedangkan kontribusi kecerdasan emosi terhadap prestasi belajar siswa sebesar 12,20\%.

Emosi berpengaruh besar pada kualitas dan kuantitas belajar. Emosi yang positif dapat mempercepat proses belajar dan mencapai prestasi belajar yang lebih baik begitu pula dengan prestasinya, sebaliknya emosi yang negatif dapat memperlambat belajar atau bahkan menghentikannya sama sekali (Khodijah, 2014).

Berdasarkan pendapat Ahmad (2015) mengkonsep diri sangat dibutuhkan dalam mengembangkan kemampuan menganalisis, memecahkan masalah, mensintesis dan menyimpulkan masalah. Kemampuan dasar inilah yang dibutuhkan dalam meningkatkan hasil belajar IPA. Oleh karena itu Gunawan (dalam Nur dan Ekasari, 2008) menyatakan bahwaa konsep diri merupakan pondasi utama keberhasilan proses pembelajaran, termasuk bagaimana seseorang meningkatkan kecerdasan emosionalnya.

Hasil pengolahan data menerangkan bahwa terdapat pengaruh yang positif dan signifikan antara konsep diri terhadap hasil belajar biologi siswa yang ditunjukkan melalui koefisien korelasi sebesar 0,77 yang tergolong tinggi dengan persentase kontribusi (sumbangan efektif) sebesar 59,29\%. Karakter ini memberikan interpretasi bahwa siswa yang memiliki konsep diri akan berbanding lurus dengan nilai hasil belajar yang diperolehnya. Artinya peningkatan konsep diri yang lebih baik dapat meningkatkan hasil belajarnya dalam mata pelajaran biologi. Diharapkan dengan dikembangkannya konsep diri siswa agar dapat memiliki kepercayaan diri yang baik terhadap kelemahan, kemampuan, sikap dan nilai diri sendiri untuk pencapaian hasil belajar yang maksimal.

Berdasarkan Hasil pengolahan data menerangkan bahwa terdapat pengaruh yang positif dan signifikan antara kecerdasan emosional dengan hasil belajar biologi siswa yang ditunjukkan melalui koefisien korelasi sebesar 0,74 yang masih tergolong tinggi dengan persentase kontribusi (sumbangan efektif) sebesar 54,76\%. Karakter ini memberikan interpretasi bahwa siswa yang memiliki kecerdasan emosional akan berbanding lurus dengan nilai hasil belajar yang diperolehnya. Artinya peningkatan kecerdaan emosional yang lebih baik dapat meningkatkan hasil belajarnya dalam mata pelajaran biologi. Diharapkan dengan dikembangkannya kecerdasan emosional siswa dapat mengolah emosinya menjadi lebih terkendali demi untuk pencapaian hasil belajar yang maksimal.

Hasil pengolahan data juga menerangkan bahwa terdapat hubungan yang positif dan signifikan antara konsep diri dan kecerdasan emosionalterhadap hasil belajar biologi siswa yang ditunjukkan melalui koefisien korelasi ganda sebesar 0,79 yang tergolong tinggi dengan persentase kontribusi (sumbangan efektif) konsep diri dan kecerdasan emosional terhadap hasil belajar biologi sebesar 62,41\%. Berdasarkan penjelasan sebelumnya, hal ini menunjukkan bahwa konsep diri yang diiringi dengan kecerdasan emosional akan lebih maksimal dalam meningkatkan hasil belajar biologi siswa. 
Goleman menggambarkan kecerdasan emosional sebagai sebuah alat rangkaian positif dalam kepercayaan diri, teliti, dan prestasi yang hanya fokus pada kecerdasan yang bisa membantu individu memecahkan masalah secara efektif (Brackett dkk, 2011). Pengetahuan dan kepercayaan sebagai pondasi untuk konsep diri bukan pada nilai, sikap, dan motivasi (Gecas, 1982). Komponen pengetahuan yang baik pada konsep diri dapat mempengaruhi kesadaran diri dari kecerdasan emosional seseorang, dimana kesadaran diri adalah kemampuan secara akurat merasakan emosi diri sendiri di dalam keadaan dan pemahaman kecenderungan diri di seluruh situasi.

Dari beberapa penjelasan tersebut, dapat disimpulkan bahwa konsep diri dan kecerdasan emosional sangat erat hubungannya dengan hasil belajar siswa. Konsep diri merupakan pondasi utama seseorang dalam meningkatkan kecerdasanintelegensinya dan kecerdasan emosional merupakan kemampuan seseorang untuk memotivasi diri sendiri untuk berhasil dalam proses belajarnya. Nur dan Ekasari (2008) menyatakan kedua hal tersebut pening untuk dikembangkan, karena merupakan kunci kesuksesan dan kebahagiaan hidup. Jadi kesuksesan seseorang dalam proses pembelajarannya dipengaruhi oleh faktor yang berasal dari dirinya sendiri.

\section{SIMPULAN}

Berdasarkan hasil penelitian yang telah diuraikan, maka kesimpulan dalam penelitian ini adalah sebagai berikut: Konsep diri siswa dikategorikan cenderung cukupyaitu sebanyak 110 siswa $(86,61 \%)$ dari 127 siswa; Kecerdasan Emosional siswa dikategorikan cenderung cukup yaitu sebanyak 119 siswa $(93,70 \%)$ dari 127 siswa; Terdapat hubungan yang signifikanantara konsep diri dan kecerdasan emosional terhadap hasil belajar biologi siswa kelas XI IPA SMANegeri Se-Kota Tebingtinggi Tahun Pembelajaran 2016/2017. Hubungan konsep diri dengan kecerdasan emosional sangatlah berkaitan terhadap hasil belajar siswa, karena jika konsep diri seseorang tidak sejalan dengan emosinya, ini bisa menghancurkan seseorang dalam segala hal, baik itu tentang kesehariannya atau pun dalam hal belajarnya untuk mencapai nilai yang maksimal dalam proses belajar mengajar yang dilakukan dimana saja dan kapan saja berlangsung siswa

\section{DAFTAR PUSTAKA}

Ahmad, N, D., (2015), Pengaruh Kemampuan Berpikir Kritik dan Konsep Diri Terhadap Prestasi Belajar IPA. Jurnal Formatif 5: 55-67

Brackett, M, A, Susan, E, R, and Peter, S., (2011), Emotional Intelligence: Implications for Personal, Social, Academic, and Workplace Success. Article

Calhoun, J., dan Acocella J, R., (1990), Psikologi Tentang Penyesuaian dan Hubungan Kemanusiaan Edisi Ketiga, IKIP Semarang Press, Semarang

Firdaus, D., (2012), Pengaruh Kecerdasan Emosional (EQ) dan Motivasi Belajar Terhadap Hasil Belajar BiologiSiswa SMA 3 Negeri Palopo, Jurnal Pendidikan dan Pembelajaran, 19(2): 243-246.

Gecas., V., (1982) The self-concept.Jurnal Annual Review of Sociology. $8: 1-33$

Goleman, D., (2001), Kecerdasan Emosi Untuk Mencapai Puncak Prestasi, Gramedia Pustaka Utama, Jakarta.

Hidayatullah, S., (2014), Hubungan Antara Kecerdasan Emosional Dengan Prestasi Belajar Siswa Pada Pelajaran PAI, Skripsi Uin Jakarta

Khodijah, N., (2014), Psikologi Pendidikan, PT Raja Grafindo Persada, Jakarta.

Mulyati., (2005), Psikologi Belajar, Penerbit Andhi, Yogyakarta

Nur F,I dan Ekasari, A., (2008), Hubungan antara konsep diri dengan kecerdasan emosional pada remaja.Jurnal Soul, 1: 15-31

Pamungkas, R.,Suhartono, dan Kartika Chrysti, (2014), Pengaruh Kecerdasan Emosional Terhadap Hasil Belajar Matematika pada Siswa Kelas V SD Se-Kecamatan Prembun. Jurnal FKIP Universitas SebelasMaret Surakarta. 5 : 15 